\title{
PEMBELAJARAN MATERI LUAS TRAPESIUM DAN LINGKARAN MENGGUNAKAN MODEL KOOPERATIF TIPE STAD SISWA SEKOLAH DASAR
}

\author{
Samsuri \\ Guru SDN 001 Teluk Sebong \\ Email:anjanxs@gmail.com
}

\begin{abstract}
Abstrak
Kurangnya pengetahuan tentang bagaimana mengimplikasikan matematika di dalam kehidupan sehari-hari, kurangnya kesiapan siswa untuk mengikuti pelajaran matematika dan kurangnya kemampuan matematika guru, menjadi kendala di dalam pembelajaran matematika. Tujuan penulisan makalah ini adalah untuk mendeskripsikan kondisi, bentuk RPP dan skenario pembelajaran Matematika di kelas VI SDN 001 Teluk Sebong, dengan menerapkan model pembelajaran STAD, dengan tahapan sebagai berikut; (1) Guru membentuk kelompok, anggotanya 3 orang secara heterogen; (2) Guru menyajikan pelajaran; (3) Guru memberi tugas pada kelompok untuk dikerjakan oleh anggota-anggota kelompok. (4) peserta didik yang bisa mengerjakan soal, menjelaskan kepada anggota kelompok lainnya sehingga semua anggota dalam kelompok itu mengerti. ; (5) Guru memberi kuis kepada seluruh peserta didik. Pada saat menjawab kuis tidak boleh saling membantu. (6) Guru memberikan penghargaan kepada kelompok yang memiliki nilai/poin; (7) Guru memberikan evaluasi; (8) Penutup. Dapat disimpulkan bahwa dengan diterapkannya model pembelajaran koopratif STAD, dapat membuat siswa aktif dalam pembelajaran.
\end{abstract}

\section{Kata Kunci: Model Pembelajaran STAD, Materi Luas Trapesium dan Lingkaran, Kegiatan Pembelajaran.}

\section{PENDAHULUAN}

Matematika merupakan satu diantara beberapa Mata Pelajaran yang diajarkan di Sekolah Dasar. Di antara semua mata pelajaran yang ada, matematika seringkali ditakuti dan tidak disenangi oleh sebagian besar siswa SDN 001 Teluk Sebong. Anggapan bahwa matematika yang penuh dengan hitungan, rumus-rumus, lambang-lambang yang membingungkan, memunculkan pengalaman yang kurang menyenangkan ketika belajar matematika. Hal tersebut tidaklah mengherankan, karena anggapan di masyarakat sendiri, matematika adalah mata pelajaran yang sulit dan tidak menyenangkan. Kurangnya pengetahuan tentang bagaimana mengimplikasikan matematika di dalam kehidupan sehari-hari, kurangnya kesiapan siswa untuk mengikuti pelajaran matematika karena kurangnya kemampuan dasar matematika dan kurangnya kemampuan matematika guru, menjadi kendala di dalam pembelajaran matematika, yang membuat matematika semakin sulit dipahami.
Indikator pencapaian kompetensi yang diharapkan dalam materi luas trapesium dan lingkaran adalah menurunkan rumus luas bangun ruang dan menghitung luas bangun ruang. Wawancara dengan teman sejawat, pemahaman siswa pada materi menghitung luas trapesium dan luas lingkaran, pada siswa tahun sebelumnya, menyatakan terdapat perbedaanperbedaan kemampuan belajar secara individu dengan kemampuan sangat baik, baik,cukup baik dan kurang baik. Pembelajaran yang dilaksanakan yakni pembelajaran konvensional atau pembelajaran yang biasa dilakukan di sekolah yakni; metode ceramah, tanya jawaab dan penugasaan. Wawancara dengan siswa juga menggambarkan bahwa siswa kesulitan dalam memahami materi tersebut. Dapat diperediksi, kesulitan pemahaman siswa terhadap materi pembelajaran, dikarenakan siswa belum mememukan cara belajar yang tepat untuknya.

Siswa juga kesulitan memahami menerapkan rumus-rumus dalam memecahkan soal matematika. Pada dasarnya, siswa memiliki pengetahuan yang beragam tentang materi yang 
diajarkan sesuai dengan pengalaman mereka. Dengan demikian dalam proses belajar siswa harus berperan aktif untuk mengubah konsepsi yang dimilikinya sesuai dengan konsep ilmiah dari materi tersebut. Dengan demikian, guru memiliki peran penting dalam memilih model pembelajaran yang dapat menciptakan pembelajaran yang kondusif, inovatif dam kreatif dengan pendekatan pembelajaran yang berorientasi kepada siswa. Guru dapat menggunakan model pembelajaran sesuai dengan pengetahuannya. Satu diantara model pembelajaran yang dapat diterapkan adalah pembelajaran kooperatif, yang ditandai dengan adanya struktur tugas, struktur tujuan dan trukutur penghargaan. Dalam pembelajaran kooperatif, siswa didorong untuk bekerjasama pada suatu tugas bersama dan mereka harus mengkoordinasikan usahanya untuk menyelesaikan tugas yang diberikan guru. Satu diantara model pembelajaran kooperatif yang dapat diterapkan adalah model pembelajaran STAD (Student Teams Achievement Divisions). Model pembelajaran STAD. Yang dimaksud Model pembelajaran STAD dalam penulisan ini adalah salah satu model pembelajaran dengan tahapan: (1) Guru membentuk kelompok, anggotanya 3 orang secara heterogen; (2) Guru menyajikan pelajaran; (3) Guru memberi tugas pada kelompok untuk dikerjakan oleh anggotaanggota kelompok. (4) peserta didik yang bisa mengerjakan tugas/soal, menjelaskan kepada anggota kelompok lainnya sehingga semua anggota dalam kelompok itu mengerti.; (5) Guru memberi kuis kepada seluruh peserta didik. Pada saat menjawab kuis/pertanyaan tidak boleh saling membantu. (6) Guru memberikan penghargaan (rewads) kepada kelompok yang memiliki nilai/poin; (7) Guru memberikan evaluasi; (8) Penutup

Menghitung Luas Trapesium dan Lingkaran. Adalah salah satu materi yang diajarkan di kelas VI semester satu. Adapun indikator yang dibahas adalah menggunakan rumus untuk mencari luas trapesium; menghitung luas trapesium jika diketahui jumlah sisi sejajar dan tingginya; Menghitung luas lingkaran jika diketahui jari-jari atau diameternya.

Menurut Sardiman (2005: 21) menyatakan bahwa "Belajar adalah sebagai suatu interaksi antara diri manusia dengan lingkungannya yang mungkin berwujud pribadi, fakta, konsep ataupun teori”. Selanjutnya Winkel (1996:53) mengemukakan "Belajar dirumuskan sebagai suatu aktivitas mental/ psikis yang berlangsung dalam interaksi aktif dengan lingkungan yang menghasilkan perubahan-perubahan dalam pengetahuan, pemahaman, keterampilan dan nilai sikap, perubahan tersebut relatif konstan dan berbekas"

Berkaitan dengan defenisi belajar, Renyi (1996:12) menyatakan "larning is show by change in behaviour as result of experence". Melalui defenisi belajarnya, Renyi mengatakan bahwa belajar ditunjukkan melalui perubahan perilaku sebagai hasil pengalaman. Pada proses belajar, siswa berinteraksi langsung dengan objek belajar menggunakan semua alat indranya. Sedangkan Cronbach 9 (dalam ahmadi, 1999:120) menyatakan bahwa "Belajar ditunjukkan melalui perubahan tingkah laku sebagai hasil dari pengalaman. Dalam proses belajar, seseorang akan berinteraksi langsung dengan objek belajar menggunakan semua alat indranya".

Soleh (1998:8) memberikan beberapa karakteristik matematika sehingga membedakannya dari mata pelajaran lain, yaitu: (a) Objek pembicaraannya abstrak. (b) Pembahasannya mengandalkan tata nalar (c) Pengertian (konsep) atau pernyataan sangat jelas berjenjang sehingga terjaga konsistensinya. (d) Melibatkan perhitungan atau pengerjaan (operasi). (e) Dapat dialihgunakan dalam berbagai aspek keilmuan maupun kehidupan sehari-hari.

Johnson dan Rising (dalam Ruseffendi, 1991:2) mendefenisikan "Matematika sebagai pengetahuan terstruktur yang terorganisir sifatsifat atau teori yang telah terbukti kebenarannya". Goldin (dalam Suryanto, 2002:) Mengatakan bahwa "Matematika ditemukan dan dibangun oleh manusia, sehingga dalam pembelajaran matematika harus lebih dibangun oleh siswa daripada ditanamkan oleh guru". Selain itu Herman Hudoyo (1988:56) menyatakan bahwa "Belajar matematika adalah belajar tentang konsep dan struktur matematika yang terdapat di dalam materi yang dipelajari serta mencari hubungan antara konsep-konsep dan struktur yang terdapat dalam arti tersebut"

Wardhani (2003:12) berpendapat bahwa "melalui belajar matematika, diharapkan pula kemampuan bernalar pada siswa yang tercermin, mampu berfikir kritis, logis dan sistematis dan memiliki sifat objektif, jujur, serta disiplin dalam memecahkan suatu 
permasalahan, baik dalam bidang matematika maupun bidang lain atau dalam kehidupan sehari-hari. Trapesium adalah segi empat yang hanya mempunyai sepasang sisi sejajar. Terdapat tiga jenis trapesium . Perhatikan gambar-gambar berikut.
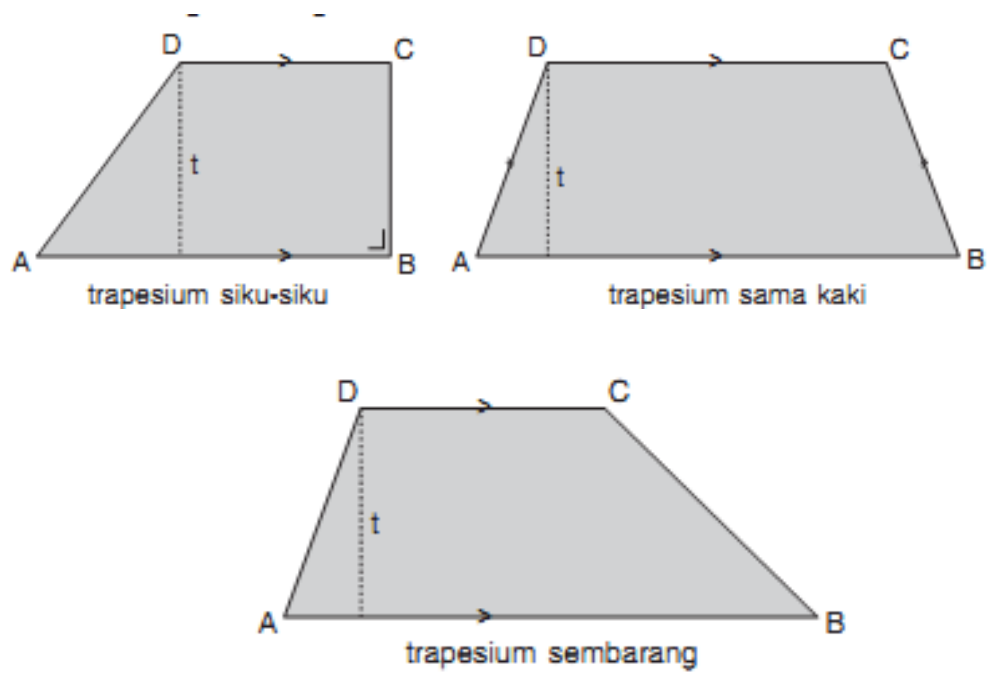

Gambar 1. Trapesium

Luas Trapesim $=$ Jumlah sisi sejajar $\mathrm{x} \frac{1}{2}$ tinggi atau Luas Trapesium $=\frac{1}{2}(\mathrm{AB}+\mathrm{DC}) \mathrm{x} \mathrm{t}$

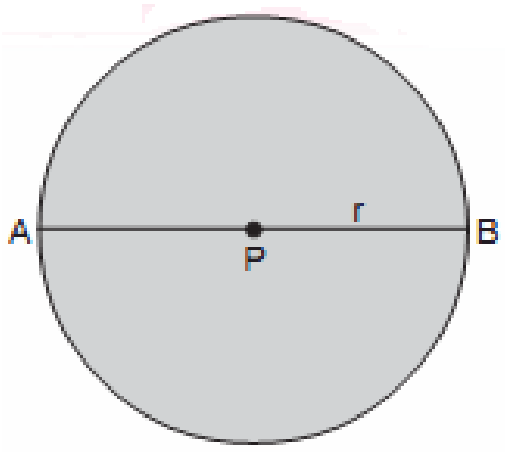

Gambar 2. Lingkaran

Suatu lingkaran dengan titik pusat $P$ mempunyai bagian-bagian sebagai berikut.(a) $\mathrm{P}$ merupakan pusat lingkaran. (b) $\mathrm{AP}=\mathrm{PB}=\mathrm{r}=$ jari-jari lingkaran. (c) $\mathrm{AB}=$ diameter lingkaran $=\mathrm{d}=$ garis tengah lingkaran. $\mathrm{AB}=\mathrm{AP}+\mathrm{PB}=\mathrm{r}$ $+r=2 \times r=2 r,=2 \times$ jari-jari lingkaran. Jika jari-jari lingkaran $=\mathrm{r}$ dan diameter $=\mathrm{d}$ maka diperoleh hubungan $\mathrm{d}=2 \times \mathrm{r}$ atau $\mathrm{r}=\frac{1}{2} \times \mathrm{d}$ Luas lingkaran $=\pi x r \times r \quad$ atau $\pi x r^{2}$ dan Luas lingkaran $=\frac{1}{4} x \pi x d x d$ atau $\frac{1}{4} x \pi x d^{2}$ Dengan $\pi=\frac{22}{7}$ atau 3,14Dalam Bistari (2015: 293) dipaparkan beberapa pengertian tentang model pembelajaran menurut para ahli sebagai berikut. (a) Ruseffendi mengungkapkan bahwa model pembelajaran adalah sebagai suatu desain yang menggambarkan proses rincian dan penciptaan situasi lingkungan yang memungkinkan siswa berinteraksi sehingga terjadi perubahan atau perkembangan pada siswa. (b) Akhmad Sudrajad mengungkapkan model pembelajaran pada dasarnya merupakan bentuk pembelajaran yang tergambar dari awal sampai akhir yang disajikan secara khas oeh guru. Dengan kata lain, model pembelajaran merupakan bungkus atau bingkai dari penerapan suatu pendekatan, metode dan teknik pembelajaran. (c) Soekamto mengungkapkan model adalah kerangka konseptual yang melukiskan prosedur yang sistematis dan mengorganisasikan pengalaman belajar untuk mencapai tujuan belajar tertentu dan berfungsi sebagai pedoman bagi perancang pembelajaran dan para pengajar dalam merencanakan aktivitas belajar mengajar. (d) Winataputra mengungkapkan model pembelajaran adalah kerangka konsepual yang melukiskan prosedur yang sistematis dalam mengorganisaasikan pengalaman belajar untuk mencapai tujuan blajar tertentu dan berfungsi sebagai pedoman bagi para pencanang pembelajaran dan para pengajar dalam mencanangkan dan melaksanakan aktivitas pembelajaran. (e) Joyce dan Marsha Weil's mengungkapkan model pembelajaran adalah suatu rancangan atau pola yang dapat digunakan untuk membentuk kurikulum (pembelajaraan dalam jangka waktu lama) untuk mendesain bahan-bahan pembelajaran dan untuk mengarahkan guru mengaajar serta setting lainnya di dalam kelas. 
(f) Agus Suprijono mengungkapkan pola yang digunakan sebagai pedoman dalam merencanakan pembelajaran di kelompok maupun tutorial.

Berdasarkan beberapa pendapat ahli di atas, dapat disimpulkan bahwa model pembelajaran merupakan prosedur yang sistematis dalam mengorganisaasikan pengalaman belajar untuk mencapai tujuan belajar tertentu dan berfungsi sebagai pedoman bagi para pencanang pembelajaran dan para pengajar dalam mencanangkan dan melaksanakan aktivitas pembelajaran. (a) Ciri-ciri model pembelajaran: Rasional teoritik yang logis yang disusun oleh para penciptaa ataau pengembaangnya. (a) Landasan pemikiran tentang apa dan bagaimana siswa belajar. (c) Tingkah laku mengajar yang diperlukan agar model tersebut dapat dilaksanakan dengan berhasil.

Sebagai seorang guru harus mampu memilih model pembelajaran yang tepat bagi peserta didik. Karena itu dalam memilih model pembelajaran guru harus memperhatikan keadaan atau kondisi siswa, bahan pelajaran serta sumber-sumber belajar yang ada agar penggunakan model pembelajaran dapat diterapkaan secara efektif daan menunjang keberhaasilan belajar siswa.Seorang guru diharapkan memiliki motivasi dan semangat pembaharuan dalam proses pembelajaraan yang dijalaninya.Guru yang kompeten adalah guru yang mampu mengelola program belajar mengaajar. Mengelola di sini memiliki arti yang luas yang menyangkut bagaimana seorang guru mampu menguasai keterampilaan dasar mengajar, seperti membuka dan menutup pelajaran, menjelaskan, memvariasi media, bertanya, memberi penguatan, dan sebagainya, juga bagaimana guru menerapkan strategi, teori belajar dan pembelajaran, dan melaksanakan pembelajaran yang kondusif.

Pendapat serupa dikemukakan oleh colin Marsh dalam Bistari (2015), yang menyatakan bahwa guru harus memiliki kompetensi mengajar, memotivasi peserta didik, membuat model instruksional, mengelola kelas, berkomunikasi, merencanakan pembelajaran dan mengevaaluasi. Semua kompetensi tersebut mendukung keberhasilan guru dalam mengajar.

$$
\text { Adapun macam-macam Model }
$$

Pembelajaran dalam Bistari 2015: antaralain: (a) Model Pembelajaran Example Non Example; (b) Model Pembelajaran Picture and Picture; (c)
Model Pembelajaran Numbered Head Together (NHT); (d)Model Pembelajaran Kooperatif Tipe Script; (e) Model Pembelajaran Kepala bernomor Struktur (Numbered Head Together= NHT); (f) Model Pembelajaran Student TeamsAchievement Divisions (STAD); (g)Pembelajaran Model Jigsaw; (h) Model Pembelajaran Berbasis Masalah (Problem Based Introduction); (i) Model Pembelajaran Mind Mapping; (j) Model Pembelajaran Make a Match; (k)Model Pembelajaran Think Pair Share (TPS); (l)Model Pembelajaran Debat Aktif; (m) Model Pembelajaran Artikulasi; (n)Model Pembelajaran Role Playing; (o).Model Pembelajaran Group Investigation.

Model pembelajaran STAD termasuk model pembelajran kooperatif. Semua model pembelajaran kooperatif ditandai dengan adanya struktur tugas, struktur tujuan, dan struktur penghargaan. Dalam proses pembelajran dengan model pembelajara kooperatif siswa didorong untuk bekerjasama pada suatu tugas bersama dan mereka harus mengkoordinasikan usahanya untuk menyelesaikan tugas yang diberikan guru.

Tujuan Model Pembelajaran kooperatif adalah prestasi belajar akademik siswa meningkat dan siswa dapat menerima berbagai keragaman dari temannya, serta pengembangan keterampilan sosial.

Berikut dipaparkan beberapa pendapat ahli, terkait pembelajaran STAD. (a) Menurut Wina Sanjaya (dalam Bistari (2015:312) menjelaskan bahwa kooperatif merupakan model pembelajaran menggunakan sistem pengelompokkan atau tim kecil yaitu 4- 5 orang yang mempunyai latar belakang kemampuan akademik, jenis kelamin, ras atau suku yang berbeda (Hiterogen). (b) Johnson dalam Bistari (2015:312) menyatakan bahwa: Pembelajaran kooperatif adalah pemanfaatan kelompok kecil dalam pembelajaran yang memugkinkan siswa bekerjasama.

Slafin dalam Bistari (2015:312) mengemukakan dua alasan bahwa: Pembelajaran kooperatif merupakan bentuk pembelajaran yang dapat memperbaiki pembelajaran selama ini. Pertama, beberapa penelitian membuktikan bahwa penggunaan pembelajaran kooperatif dapat meningkatkan prestasi belajar siswa sekaligus dapat meningkatkan kemampuan hubungan sosial, menumbuhkan sikap menerima kekurangan diri dan orang lain, serta dapat meningkatkan harga diri. Kedua, pembelajran kooperatif dapat merealisasikan kebutuhan siswa dalam belajar, berpikir, memecahkan masalah, 
dan mengintegrasikan pengetahuan dengan keterampilan.

Dalam Bistari (2015:315) menyatakan bahwa terdapat kelebihan dan kekurangan model Pembelajaran Tipe STAD dan hubungan Model STAD dan prestasi. Kelebihan Model Pembelajaran tipe STAD antara lain; (a) Meningkatkan kecakapan individu; (b)Meningkatkan kecakapan kelompok; (c) Meningkatkan komitmen; (d) Mehilangkan prasangka buruk terhadap teman sebaya; (e) Tidak bersifat kompetitif; (f) Tidak memiliki rasa dendam.

Kekurangan Model Pembelajaran Kooperatif STAD antara lain; (1) Konstribusi dari siswa berprestasi rendah menjadi kurang; (2) Siswa berprestasi tinggi akan mengarah kepada kekecewaan karena peran anggota yang pandai lebih dominan.

Hubungan penerapan model pembelajaran STAD dengan motivasi dan prestasi Belajar Siswa adalah dalam proses belajar mengajar guru sebagai pelaksana pengajaran harus dapat menciptakan kondisi yang daapat melibatkan siswa secara aktif. Dengan demikian diharapkan terjadi interaksi antara guru dan siswa yang pada umumnya akan merasa mendapat motivasi yang tinggi apabila guru melibatkan siswa secara aktif dalam proses belajar mengajar. Pembelajaran kooperatif dapat meningkatkan motivasi belajar siswa secara konsisten baik bagi siswa yang memiliki kemampuan yang tinggi, sedang dan rendah dan resistensi (daya lekat) terhadap materi pelajaran menjadi lebih panjang (Ellyana dalam Bistari 2015:316)

\section{PEMBAHASAN PERMASALAHAN}

Lokasi SDN 001 Teluk Sebong beralamat di Pemukiman Segiling Desa Sri Bintan Kecamatan Teluk Sebong Kabupaten Bintan. Sekolah ini terletak di daerah yang jauh dari keramaian dan jauh dari kota, keadaan penduduk yang tidak ramai sehingga jumlah siswa dan siswi yang ada juga sedikit. Sekolah ini merupakan sekolah yang bangunan fisiknya yang masih semi permanen, memiliki 6 kelas dan tidak mempunyai ruang majlis guru, tidak mempunyai perpustakaan. Akses internet di sekolah ini kurang baik sehingga kurangnya menunjang dalam proses pembelajaran.
Pembelajaran yang biasa dilakukan guru saat ini, cenderung pada pembelajaran masih terfokus pada guru. Kegiatan pembelajaran yang dilakukan guru untuk beberapa bulan terakhir terkesan tidak mengalami kemajuan. Hasil Belajar siswa belum memuaskan. Hanya siswa yang berkemampuan di atas rata-rata yang mengalami kemajuan belajar yang berarti.

Jumlah siswa kelas VI SDN 001 Teluk Sebong 6 orang yang terdiri dari 3 siswi perempuan dan 3 siswa laki-laki . Dari 6 Siswa tersebut, 1 diantaranya tergolong siswa berkemampuan di atas rata-rata, 2 tergolong siswa berkemampuan sedang dan 3 siswa berkemampuan di bawah. Adapun Kemampuan belajar Matematika siswa kelas VI, rata-rata dibawah KKM. Hanya 1 Siswa yang kemampuannya diatas rata-rata. 5 siswa yang lain berkemampuan kurang.

Cara pembelajaran guru yang dilakukan pada siswa, cenderung dilakukan dengan metode ceramah. Namun demikian, guru mencoba untuk memvariasikan metode pembelajaran dengan model pembelajaran yang lain, seperti model pembelajaran tipe STAD. Dalam penulisan makalah ini guru mencoba membuat rancangan pelaksanaan pembelajaran dengan model pembelajaran kooperatif tipe STAD. Beberapa kondisi yang diharapkan penulis adalah munculnya sifat kerjasama dan saling membantu secara positif diantara siswa. Disamping itu, jika ini dijalankan dengan tertib maka memungkinkan siswa terbiasa dengan beberapa karakter yang dikembangkan.

Skenario Pembelajaran Matematika pada materi Luas Prisma dan Lingkaran dengan Model Pembelajaran STAD di kelas VI SDN 001 Teluk Sebong : (1) Mengucapkan salam: Saat guru masuk kelas, guru langsung mengucapkan salam pada seluruh dan siswa secara spontan menjawab salam dari guru tersebut. Selanjutnya ketua kelas memimpin seluruh siswa untuk membaca doa belajar secara bersama-sama. Setelah itu, seorang siswa memimpin lagu Indonesia Raya, siswa yang lain menyanyikan lagu Indonesia Raya.(2) Mengecek kesiapan siswa. Guru bertanya kepada siswa tentang bagaimana kabar mereka? siswa spontan menjawab pertanyaan guru tersebut. Guru juga menanyakan apakah siswa sudah siap mengikuti kegiatan pembelajaran. Siswa spontan menjawab menjawab pertanyaan guru. (3) Apersepsi, Guru menyampaikan apersepsi materi pembelajaran yang telah lalu tentang bangun-bangun datar. Sambil bertanya jawab. 
Siswa menjawab pertanyaan guru.

Menyampaikan tujuan pembelajaran

Guru menyampaikan tujuan pembelajaran. Guru menyampaikan harapan- harapan yang ingin dicapai setelah pembelajaran Siswa mendengarkan tujuan pembelajaran yang disampaikan guru. (5) Memotivasi. Guru menyampaikan motivasi kepada siswa. Memberikan siswa semangat belajar dengan menyebutkan manfaat mempelajari materi menghitung luas trapesium dan lingkaran, yang dapat diterapkan dalam kehidupan sehari hari, seperti dengan mengetahui cara menghitung luas lingkaran, kita dapat menghitung berap banyak air yang dapat diisikan di dalam sebuah tong air bebentuk lingkaran maupun yang berbentuk trapesium. Guru juga menyampaikan bahwa materi menghitung luas trapesium dan luas lingkaran terdapat di dalam SKL (Standar Kompetensi Lulusan), yang merupakan kisi-kisi soal ujian matematika SD kelas VI. Jadi sangat beruntung sekali jika siswa memahami materi tersebut, guna dapat menjawab soal ujian tentang menghitung luas trapesium dan luas lingkaran. Dikarenakan hal tersebut, diharapkan siswa bertambah motivasi belajarnya.

Kegiatan inti meliputi: (1) Guru membentuk kelompok, yang anggotanya 3 orang secara heterogen. Guru membagi siswa menjadi beberapa kelompok kecil yang anggotanya 3 orang, dengan kombinasi berbeda kemampuan intelektualnya, berbaur laki-laki dan perempuan, berbeda kemampuan bekerjasamanya dan sebagainya. (2) Guru menyajikan pelajaran tentang menghitung luas trapesium dan luas lingkaran. Dalam kegiatan ini guru memperlihatkan alat peraga berbentuk trapesium dan lingkaran . guru bertanya jawab tentang sifat-sifat kedua bangun tersebut. Siswa secara bergantian maju menunjukkan bagian bagian kedua bangun tersebut, mulai dari jumlah sisi, jumlah titik sudut, jumlah rusuk. Jumlah sisi lengkung yang ada. Guru menjelaskan bahwa rumus Luas dapat ditemukan dari mengalikan luas alas dengan tinggi bangun yang dicari luasnya. (3) Guru memberi tugas pada kelompok untuk dikerjakan oleh anggota-anggota kelompok. (4) Peserta didik yang bisa mengerjakan tugas/soal menjelaskan kepada anggota kelompok lainnya sehingga semua anggota dalam kelompok itu mengerti. (5) Guru memberikan kuis kepada seluruh peserta didik. Pada saat menjawab kuis/pertanyaan tidak boleh saling membantu. Peserta didik yang mampu menjawab pertanyaan, mengacungkan jari untuk memdapat giliran menjawab kuis. Guru mempersilakan siswa yang mengacungkan jari menjawab pertanyaan. Jika jawabannya benar, maka kelompoknya akan mendapat poin.jika jawabannya belum benar, maka kelompoknya tidak akan mendapat poin. Dan soal kuisnya diajukan kembali ke pada siswa yang lain, dari kelompok lain. (6) Guru memberikan penghargaan (rewards) kepada kelompok yang memiliki nilai/poin. Kelompok siswa yang mendapat poin akan termotivasi menambah poin, kelompok siswa yang belum mendapat poin akan termotivasi ingin mendapatkan poin. Rewards yang diberikan dapat berupa benda, maupun tepukan semangat, ataupun yang lainnya yang dapat siswa gembira jika memperolehnya. (7)Guru memberikan evaluasi kegiatan pembelajaran. Siswa menyelesaikan soal evaluasi yang dibagikan guru secara individual. Guru menentukan waktu maksimal menyelesaikan evaluasi. Jika waktu evaluasi telah mencapai batas maksimal, pekerjaan siswa harus dikumpulkan, selesai maupun tidak selesai. Guru bersama siswa mengoreksi bersama hasil evaluasi.

Kegiatan Penutup, (1) Guru menyimpulkan materi. Pada kegiatan ini, guru membimbing siswa menarik kesimpulan tentang materi pelajaran yang telah diajarkan. Pendapat yang dikemukakan siswa yang sesuai dapat dijadikan kesimpulan, ditulis di papan tulis oleh guru. Kesimpulan yang belum tepat, disempurnakan dulu oleh guru.Setelah materi selesai disimpulkan, siswa mencatnya di buku tulisnya masing-masing. (2) Guru bertanya jawab tentang hal-hal yang belum diketahui siswa. Bagi siswa yang belum jelas tentang materi, siswa dapat mengajukan pertanyaan kepada guru. Pertama, guru akan menyerahkan kepada siswa lain jika ada yang dapat menjawab pertanyaan dari temannya yang bertanya. Jika didak ada yang dapat menjawab, barulah guru menjawab pertanyaan tersebut (3) Guru memberikan pekerjaan rumah dan menginformasikan materi yang akan dibahas pada pertemuan selanjutnya. Pekerjaan rumah yang dimaksud memuat pertanyaan yang baru saja dipelajari. Jika siswa kesulitan dalam menyelesaikan soal pekerjaan rumah tersebut, siswa dapat minta bantuan teman kelompoknya yang bisa. menginformasi materi yang akan dibahas pertemuan selanjutnya, siswa diminta membaca materi tersebut di rumah. 


\section{SIMPULAN DAN SARAN \\ Simpulan}

Berdasarkan paparan dari pembahasan dapat disimpulkan: 1. Siswa kelas VI SDN 001 Teluk Sebong 2019/2020 memerlukan model pembelajaran kooperatif, dimana siswa yang berkemampuan di atas rata-rata berkerjasama bersama siswa yang berkemampuan di bawah rata-rata, dalam memahami materi luas trapesium dan lingkaran. Selanjutnya, diharapkan memiliki kemudahan dalam memahami konsep; 2. RPP Matematika pada materi menghitung luas trapesium dan lingkaran dengan Model Pembelajaran STAD di kelas VI SDN 001 Teluk Sebong, pada kegiatan inti dengan tahapan sebagai berikut; (1) Guru membentuk kelompok, anggotanya 3 orang secara heterogen; (2) Guru menyajikan pelajaran; (3) Guru memberi tugas pada kelompok untuk dikerjakan oleh anggotaanggota kelompok. (4) peserta didik yang bisa mengerjakan tugas/soal, menjelaskan kepada anggota kelompok lainnya sehingga semua anggota dalam kelompok itu mengerti. ; (5) Guru memberi kuis kepada seluruh peserta didik. Pada saat menjawab kuis/pertanyaan tidak boleh saling membantu. (6) Guru memberikan penghargaan (rewads) kepada kelompok yang memiliki nilai/poin; (7) Guru memberikan evaluasi; (8) Penutup; 3.Dalam skenario pelaksanaan pembelajaran menggunakan model pembelajaran STAD, dimungkinkan dapat menciptakan pembelajaran aktif. Hal ini disebabkan pelaksanaan pembelajaran yang dilakukan dalam kelompok sehingga siswa lebih dominan dalam proses pembelajaran. Siswa dapat menjadi lebih termotivasi dalam pembelajaran karena menggunakan sistem kooperatif dan kompetitif.

\section{Saran}

Berdasarkan pembahasan dan kesimpulan di atas, dapat disarankan beberapa hal sebagai yaitu: 1. Mengajar menggunakan model pembelajaran STAD, ketepatan pembagian anggota kelompok siswa yang heterogen dari segi kemampuan intelektual, jenis kelamin, maupun kemampuan kerjasamanya. Dengan demikian hasil yang diharapkan dari diterapkannya model pembelajaran tersebut dapat maksimal. 2. Guru hendaknya menguasai materi pembelajaran dan benar-benar memahami model pembelajaran yang diterapkannya, agar dapat mengatasi kendala yang mungkin terjadi di dalam kegiatan pembelajaran.

\section{DAFTAR PUSTAKA}

Ahmadi, F. (1999). Psikologi Umum. Bandung: Pustaka Setra

Bistari. (2015). Mewujudkan Penelitian Tindakan Kelas (Kenaikan Pangkat Bagi Guru). Pontianak: PT. Ekadaya Multi Inovasi

Hudoyo, H. (1998). Belajar Mengajar Matematika. Jakarta: Depdikbud.

Ruseffendi, E.T. (1991). Pengantar Kepada Guru Mengembangkan Kompetensinya Dalam Pengajaran Matematika Untuk Meningkatkaan CBSA. Bandung: Tarsito

Sardiman (2005). Interaksi dan Motivasi Belajar Mengajar. Jakarta: PT. Raja Grafindo Persada.

Soleh, M. (1998). Pokok-pokok Pengajaran Matematika Sekolah. Jakarta: Balai Pustaka.

Suryanto. (2000). Matematika Humanistik dan Kaitannya Dengan Pembelajaran AktifEfektif. Surabaya: Usaha Nasional

Wardhani, I.G.A.K (2003). Konsep dan Masalah Pengelolaan Kelas. Buku Materi Pokok. Model 1-6. Jakarta: Pusat Penerbitan Universitas terbuka.

Winkel, W.S. (1996). Psikologi Pengajaran. Jakatra:

Gramedia. 